\title{
HYPERTROPHY OF THE FLEXOR HALLUCIS LONGUS MUSCLE AFTER TENDON TRANSFER IN PATIENTS WITH CHRONIC ACHILLES TENDON RUPTURE
}

Maria Oksanen

Syventävien opintojen kirjallinen työ

Tampereen yliopisto

Lääketieteen yksikkö

Marraskuu 2013 
MARIA OKSANEN, HEIDI HAAPASALO, PETRA ELO, HEIKKI-JUSSI LAINE:

HYPERTROPHY OF THE FLEXOR HALLUCIS LONGUS MUSCLE AFTER TENDON TRANSFER IN PATIENTS WITH CHRONIC ACHILLES TENDON RUPTURE

Kirjallinen työ, $16 \mathrm{~s}$.

Ohjaaja: LT Heidi Haapasalo

Marraskuu 2013

Avainsanat: flexor hallucis longus transfer, MRI imaging, isokinetic strength

Flexor hallucis longus (FHL) -lihaksen jännesiirto on havaittu hyväksi tavaksi hoitaa kroonisia akillesjännerepeämiä. Tutkimuksen tarkoitus oli arvioida kliinistä lopputulosta ja mahdollista FHL-lihaksen hypertrofiaa potilailla, joilla oli krooninen akillesjänneruptuura ja joille oli tehty FHL-jännesiirto.

Seitsemälle kroonisesta akillesjännerepeämästä ja sen aiheuttamasta subjektiivisesta kävelyvaikeudesta kärsivälle potilaalle tehtiin FHL-jännesiirto käyttäen yhtä leikkausvilitoa. Potilaat arvioitiin kliinisesti 27 (16-39) kuukautta leikkauksen jälkeen. Potilaiden tyytyväisyyttä arvioitiin Achilles Tendon Rupture Scale (ATRS) -kaavakkeella. Nilkan isokineettinen voima ja passiivinen liikelaajuus mitattiin käyttäen isokineettistä dynamometriä. FHL-lihaksen hypertrofiaa arvioitiin molempien säärien magneettikuvauksella. Potilaille tehtiin myös kävelymattoanalyysi (GAITRite®).

Isokineettisen plantaarifleksiovoiman havaittiin olevan -16.1\% (-45.7-2.4\%) heikompi leikatulla puolella kulmanopeudella $301 / \mathrm{s} \mathrm{ja}-2.7 \%(-70.0-6.4 \%)$ heikompi kulmanopeudella 90 1/s. Potilaat saivat ATRS-pisteitä keskimäärin 70.3 (36-96). FHL-lihaksen suurin poikkipinta-ala havaittiin 52\% (9-104\%) suuremmaksi leikatussa raajassa. Kävelymattoanalyysissä ei tullut esiin patologista kävelyä leikatun jalan huonommasta plantaarifleksiovoimiasta huolimatta.

Kroonisesta akillesjännerepeämästä kärsivillä potilailla FHL-jännesiirto antoi hyvän toiminnallisen tuloksen. 


\section{SISÄLLYS}

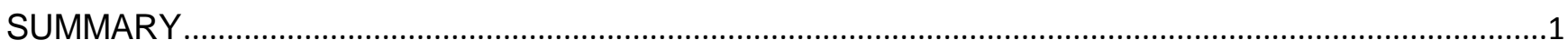

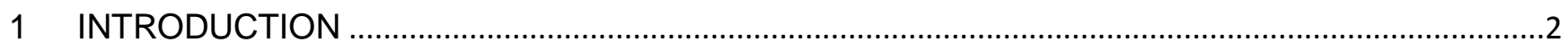

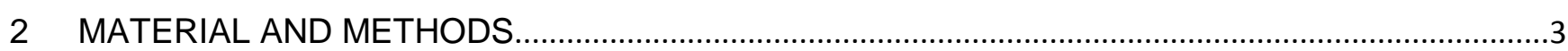

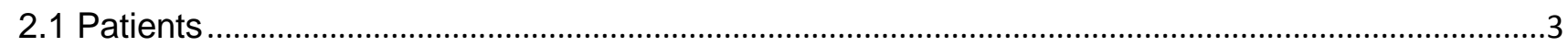

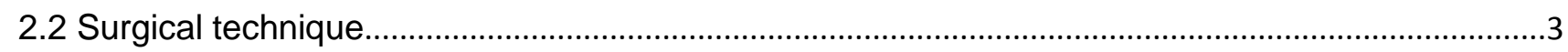

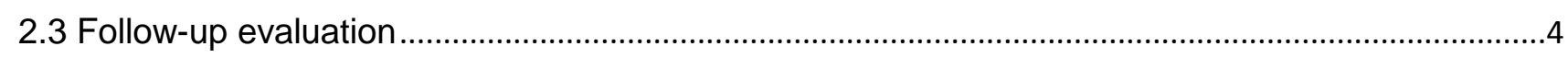

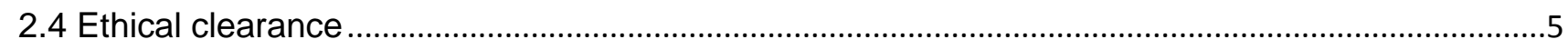

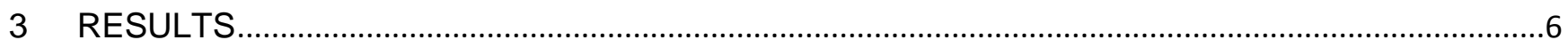

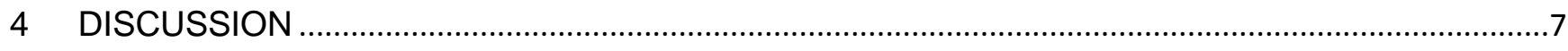

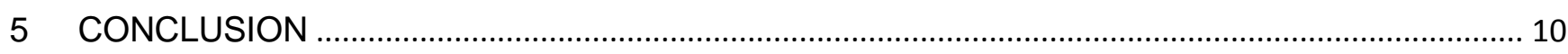

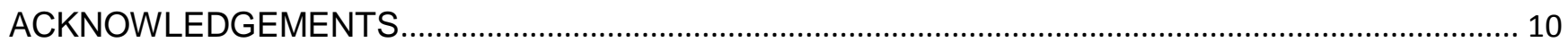

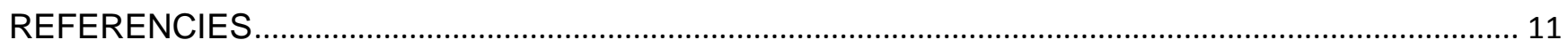

TABLE 1: Characteristics of the study subjects .............................................................................. 13

TABLE 2: ATRS scores, side-to-side differences (\% from nonoperated) in ROM, isokinetic plantar flexion strength and cross-sectional areas of FHL and calf. .............................................................. 14

FIGURE 1: Marked hypertrophy of the Flexor Hallucis Longus (FHL) muscle three years after FHL tendon transfer due to chronic achilles tendon rupture in 69 -yr-old woman.......................................... 15

FIGURE 2 The surgical field of Flexor Hallucis Longus Transfer through single incision. Proximal and distal Achilles tendon stumps (solid arrows). FHLT (open arrow)..... 


\section{SUMMARY}

Background: Flexor Hallucis Longus Tendon (FHLT) transfer has become a popular method for reconstructing a chronic Achilles Tendon Rupture (ATR). The purpose of this study was to evaluate the clinical outcomes and possible hypertrophy of the FHL muscle after FHLT transfer in patients with chronic ATR.

Methods: Seven patients with chronic ATR underwent an FHLT transfer to heel through single incision. The patients were clinically evaluated 27 (16-39) months after the surgery. The patient satisfaction was assessed with Achilles Tendon Total Rupture Scale (ATRS). Isokinetic strength was measured from both legs. The FHL muscle hypertrophy was evaluated from MRI of both legs. All subjects also performed a gait analysis with an instrumented walkway system (GAITRite®).

Results: The plantarflexion strength was $16.1 \%(45.7-2.4 \%)$ weaker in the operated leg. ATRS scores averaged 70.3. Marked hypertrophy, $+52 \%$ (9-104\%) of the FHL muscle was seen in the operated leg compared to the non-operated leg. The gait analysis did not show any marked pathology in any of the patients.

Conclusions: A mean hypertrophy of $52 \%$ of the FHL muscle was found after FHLT transfer for the chronic ATR. This indicates strong adaptation capacity of this muscle after FLHT transfer in situation where the function of the gastro-soleus complex was severely impaired preoperatively. The reconstruction of chronic ATR with FHLT transfer provided good functional outcome and excellent patient satisfaction. 


\section{INTRODUCTION}

The main problem in managing chronic Achilles tendon rupture (ATR) is the lack of the tissue between the retracted stumps [1]. The repair usually requires some kind of tendon reinforcement (augmentation) with a turndown flap, tendon transfer, tendon graft, or synthetic materials $[2,3]$. If the gap between tendon stumps is large, or if there is marked degeneration of the gastro-soleus muscle complex, tendon transfers provide a viable option for reconstruction.

Flexor hallucis longus tendon (FHLT) transfer has become a popular method for reconstructing a chronic ATR [4-12]. This method has many advantages. Firstly, the FHLT transfer can be carried out through a single incision, which makes the transfer a quite simple procedure. Secondly, proximity to the Achilles tendon avoids the need to disturb the lateral compartment or the neurovascular bundle, and the distal musculature of the FHL may provide some vascularity to the degenerated Achilles tendon $[3,4,13]$. Thirdly, the $\mathrm{FHL}$ is a strong ankle plantar flexor, having similar contractile axis and phase with gastrosoleus.

Several small patient series have shown good results with FHLT transfer [4-12]. The previous results have shown that the plantar flexion strength of the operated side cannot be fully restored, but most of the patients have been able to re-enter their previous sports interests. These studies also show very low failure rates after the FHLT transfer [4-7, 9-13]. Hypertrophy of the FHL muscle after FHLT transfer has been previously reported in a series where majority of the patients were treated due to Achilles tendinopathy [5]. To our knowledge, there are no previous reports of FHL muscle hypertrophy specifically after FHLT transfer for chronic ATR.

The purpose of this retrospective study was to evaluate the clinical outcome and crosssectional area of the FHL muscles after FHLT in patients who had presented with difficulties in walking due to chronic ATR. 


\section{MATERIAL AND METHODS}

\subsection{Patients}

From 2008 to 2010 ten patients with a chronic ATR had undergone an augmentation with FHLT transfer in our clinic. All patients were asked to participate to this retrospective study in 2012. Seven out of ten patients signed an informed consent and were enrolled in the study. Three patients had received corticosteroid injections due to Achilles tendon problems before primary ATR. The right limb was affected in four cases and the left in the three. Three patients smoked regularly. Five patients had been unable to continue in their regular sporting activity. Preoperatively all the patients reported difficulties and discomfort in daily living and normal walking.

Patients were operated three to 52 months (mean 16 months) after the ATR by a single surgeon (H-J.L.). The follow-up evaluation was performed at 27 months (range, 16-39 months) after the surgery. The subject characteristics are listed in Table 1. Four men and three women with a mean age of 53 years (range, 37-69 years) participated. All patients had suffered a previous total ATR. In two patients the primary diagnosis of ATR was delayed. In three patients the primary rupture was treated conservatively. Two of them had a re-rupture, and in one patient the conservative treatment had failed. One patient had a marked deficiency in ankle plantar flexion strength after primary surgery. One patient had a residual AT defect following revision surgery for a deep wound infection following a primary AT repair.

\subsection{Surgical technique}

The operation was performed through a single incision placed posteromedially to the Achilles tendon [14]. The Achilles tendon was exposed and the proximal and distal tendon stumps were prepared free from the surrounding tissue. The fibrous scar tissue, if present, was preserved. The deep fascia was divided and FHL muscle and tendon were indentified. The FHLT was tenotomized as distal as possible while keeping the foot maximally plantar flexed. 
The FHLT was fixed to calcaneus just anterior to Achilles tendon insertion with one bone suture anchor (TwinfixTM 5,0mm , Smith\&Nephew) keeping the ankle in a plantar flexed position. The FHLT tension was considered optimal if the FHLT was maximally tight when the ankle was in a neutral position or only a few degrees in dorsiflexion. In practice this tension is usually achieved when the lowest portion of the FHL muscle comes in contact with the calcaneus. Postoperatively ankles were immobilized in non-weight bearing equinus (ankle 2030 degrees in plantar flexion) cast for four weeks. After four weeks a functional brace was applied and daily active motion exercises and partial weight-bearing were started. The brace was removed and full weight-bearing was allowed after 8 weeks.

\subsection{Follow-up evaluation}

The patients were evaluated at the mean of 27 (16-39) months after the surgery. The clinical evaluation was not blinded and was carried out by one person who had not been involved in the previous treatment of the patients (M.O.). In the clinical examination the integrity of the FHLT and remnant Achilles was evaluated by palpation. The largest circumference from the operated leg was measured and then compared to the circumference at the same level on the other leg. The level was determined by measuring the distance from distal pole of patella with knee at 90 degrees flexion. Patients were evaluated if they were able to walk on their toes and heels. The flexion force of the IP joint was manually tested and compared to the healthy side. All study subjects filled the ATRS questionnaire, which has shown good reliability, validity and sensitivity for measuring outcome after treatment in patients with a total Achilles tendon rupture [11].

Ankle plantarflexion and dorsiflexion isokinetic strength was measured at the velocities of 30 and $90 \%$ with a Dyna-com 650 dynamometer (Oy Diter-Elektroniikka Ab, Turku, Finland). During testing shoulders were stabilized using straps, a thigh bolster was set over the tested leg and a cuff was placed around their forefoot. The knees were flexed to 90 degrees. The passive ankle ROM was measured. The isokinetic strength measurements were with active ROM between $10^{\circ}$ of ankle dorsiflexion and $20^{\circ}$ of plantarflexion. Before data collection was started, the subjects had performed one or two practice repetitions at the first angular velocity. 
Subjects were encouraged to make a maximal effort two times, and the better result of those two was counted. ROM measurements and power assessment were carried out on both legs.

The gait analysis was conducted with an instrumented walkway system (GAITRite®). The standard GAITRite walkway contained six sensor pads encapsulated in a roll-up carpet with an active area of $3.7 \mathrm{~m}$ in length and $0.6 \mathrm{~m}$ wide. The analysis was done with two walking speeds: first with the speed which is typical or natural to them and secondly they were instructed to walk 'as quickly as possible'. Two rounds at both speeds were performed. Mean values were counted for the normal and fast walking speeds, temporal and spatial gait parameters. Footfall patterns for both feet were averaged from all performed steps.

Postoperative MR imaging was done with 1.5T scanner by using a dedicated coil (Siemens Magnetom Avanto, Siements healthcare, Erlangen Germany) on both lower legs with sagittal and transaxial T1 SE- and turbo inversion recovery TIRM sequences.

The cross-sectional area of the FHL muscle and the total cross sectional area of calf were measured by at their largest sections on the operated limb. The corresponding areas were then measured at the same level on the other leg referring the same distance from the talocrural joint. Any evidence of muscle oedema fat replacement was recorded. The MRI scans were analysed by a musculoskeletal radiologist (P.E.). The side-to-side percentual differences were calculated using contralateral healthy side as a control.

\subsection{Ethical clearance}

The study protocol was reviewed and approved by the Ethical Committee of the University Central Hospital of Tampere. 


\section{$3 \quad$ RESULTS}

The continuity of the all transferred FHL tendons was considered intact. Two patients reported occasional swelling and one patient had intermittent pain on the operated area. Five patients were able to walk on their toes and all seven on their heels. Mean side-to-side difference in mid-calf circumference was $-2 \mathrm{~cm}$ (range, $-4-1 \mathrm{~cm}$ ). When clinically tested, all the patients showed diminished strength in the first interphalangeal joint flexion without causing any impairment in the daily living. The ATRS scores averaged 70 (range, 38-96. Note: Max. Possible $=100$ ) (Table 2.). All the patients were pleased to the result of the surgery and felt that the overall function of the leg was better than preoperatively. All patients would undergo the procedure again if needed.

The passive ankle ROM was reduced both in dorsiflexion (mean -26.9, range -50.2\% - 19.5\%) - and plantarflexion (-16.6\% - 20.0\%) in the ATR side compared with the other ankle. The isokinetic plantarflexion strength was $-16.1 \%$ (range $-45.7-2.4 \%$ ) weaker in the ATR side at 30 degrees/sec and $-26.7 \%(-70.0-6.4 \%)$ at 90 degrees/sec compared to control side (Table 2). The gait analysis did not show differences in stance time, step length, temporal and spatial gait parameters or the footfall patterns between legs, and all measured values were inside normative values given by the manufacturer.

In the MRI strong fatty degeneration of the soleus muscle was detected in two patients and mild fatty degeneration in four patients. Two patients had oedema in the area of gastrocnemius-soleus muscle complex. There was no fatty atrophy of the FHL muscle. Marked hypertrophy of the FHL muscle was seen in the ATR side in all study subjects. The cross-sectional area of the FHL muscle was larger (mean $51.5 \%$, range 8.6-103.7\%) on the ATR side compared to control side, whereas the total cross sectional area of calf was on average $-12.2 \%$ (range $-25.8 \%-+6.6 \%$ ) smaller in the ATR side (Table 2.).

There were no postoperative complications. 


\section{DISCUSSION}

The aim of this study was not only to evaluate the clinical outcome of the patients after the FHLT transfer surgery, but also to find out how the transferred FHL muscle adapts to its increased loading demands. The study of Hahn et al. [5] showed $17 \% \mathrm{FHL}$ muscle hypertrophy in the operated limb compared with the non-operated limb. In their study, 4 out of 13 patients however, had smaller volume on the operated side. In our study, the side-to-side difference in FHL area was larger, $51.5 \%$ on average, and in 6 out of 7 patients the side-toside difference was larger than $37 \%$. The total cross sectional area of calf was $-12.2 \%$ less in the operated leg area. In our study, all patients were operated due to the ATR causing marked functional deficiency, whereas in the study of Hahn et al. the main indication was chronic Achilles tendinopathy.

Our findings suggest that the transferred FHL muscle is capable to produce enough plantar flexion force for normal walking after chronic ATR. However, two years after the FHLT transfer surgery, the plantar flexion force is still less than in healthy leg. During this time the FHL muscle showed noticeable hypertrophy, which suggests that the FHL muscle seems to have good capacity to adapt to the new loading demands in a situation where the all the power of the gastro-soleus complex has been lost preoperatively. Due to the limited number of patients we have not correlated the hypertrophy findings to the plantar flexion strength. Factors like tensioning and the calcaneal insertion site of the FHLT may also affect the optimal function of the FHL muscle and the overall plantar flexion force. Further investigation is needed.

All patients in our study were able to return to their pre-injury activities despite the slight plantar flexion force deficiency in isokinetic measurements was observed (average $-16.1 \%$ and $-26.7 \%$ ) in the operated leg. Previous studies have shown comparable results [4-9, 1316]. In the study of Wegrzyn et al. [8] the postoperative deficit in plantar flexion torque averaged $28 \%$, and $41 \%$ in the study of Wapner et al. [4]. Interestingly, in studies where 
FHLT transfer was performed mainly due to the chronic Achilles tendinopathy, the deficits in plantar flexion strength have been of similar magnitude; $35 \%$ in the study of Hahn et al. [5] and $28 \%$ in the study of Monroe et al. [10]. Making far-reaching conclusions of the strength measurements between studies is difficult due to the small patient series, different time from operation to measurements, and large variation between patients due to their age and physical demands. In all patient series after FHLT transfer, however, most of the patients have been very satisfied and have been able to return to their daily activities.

This study also showed that FHLT transfer using a technique with a single incision and tendon fixation with a bone anchor, provided comparable results to those patient series where two incision technique or tendon fixation through a calcaneal bone tunnel were used $[5,6,8]$. A single incision technique with a fixation bone anchor or interference screw can be performed from relatively short skin incision and without exposure of the calcaneus for preparing the bone tunnel. This may play a role especially when treating patients with potential wound healing problems. In the study of Mahajan et al [11] they treated 36 elderly patients (aged 5678) with a two incision technique due to chronic ATR. 33 of the patients were very satisfied with the results. 5 out of 36 patients developed wound healing problems, one of them needed debridement. In the study of Yeoman et al. [9] 11 patients were treated with one incision ('short' FHL) technique and interference screw fixation. Their results showed reliable outcome and low morbidity; two of their patients developed complications (one DVT, one superficial wound infection). In our study with single incision tehcnique and one bone anchor, none of the patients developed postoperative complications. This finding further supports the previous findings of low morbidity with the single incision technique.

The single incision technique has been criticized for not allowing weaving of the FHL tendon through the Achilles tendon stump or double-bridging of the structural deficit in Achilles tendon. Some authors propose the complete excision of the degenerative Achilles due to better pain relief [4]. In recent series, however, preservation of the fibrous scar tissue has been suggested to make the tendon length assessment easier and the scar tissue is thought to work as a scaffold for the transferred FHLT $[5,6,8]$.In fact, this scar tissue has been shown to have the capacity to form a tendon like repair tissue [16-18]. In our study, the tendon 
stumps were preserved, and possible deficits were bridged with single strand of FHL tendon only. No failure of the FHLT transfer occurred during the follow-up period. Also all previous studies with FHLT transfer, despite the single or double incision technique, preserving or not the scar tissue, have shown very low failure rates $[5,6,8,9,12,16-18]$.

The FHLT transfer has been criticized due to the potential development of an asymmetric gait due to the deficiency in the hallux IP flexion force. In the two incision technique the distal FHL tendon is sutured with the FDL at the knot of Henry [4] potentially preserving the IP flexion force better than the single incision technique without this suturing [19]. The study of Coull et al [20] found that despite loss of active interphalangeal joint ROM, there was no impairment of walking, running, stair climbing or rising from a crouched position because of weakness of the great toe. Hanh et al [5] had results that despite the two incision technique and tenodesis, the spontaneous position of the big toe was slightly more dorsally extended than on the nonoperated foot in 6 out of 13 patients. Two of them were disturbed by the situation when putting on socks. In our series none of the patients experienced discomfort because of the inability to flex the IP joint. If tested, all patients in our study had slight impairment of hallux IP flexion force, but this had not caused any functional impairment. Also the postoperative gait analysis was not able to show any pathology.

The weaknesses of this study are the retrospective study design, small number of patients and therefore the lack of statistical analysis. Also, we do not have preoperative gait-analysis or MRI scans of the patients. However, all the patients were operated and treated pre- and postoperatively with the same surgeon and operative technique with a long follow-up time.

This study is also the first to show the strong adaptive capacity of FHL muscle in a group of patients with chronic Achilles tendon rupture. We also showed that our operative technique with minimal exposure and minimal debridement of the tendon provided comparable results with previous studies without any postoperative complications. We feel that these findings further encourage the use of FHLT transfer over other techniques in the treatment of chronic or neglected Achilles tendon rupture. More information and studies are needed to assess the 
optimal tension and insertion site of the FHLT, as well as the postoperative treatment to maximize the function of the leg.

\section{CONCLUSION}

A mean hypertrophy of $52 \%$ of the FHL muscle was found after FHLT transfer for the chronic ATR. This indicates a strong adaptation capacity of this muscle after FLHT transfer in a situation where the function of the gastro-soleus complex was severely impaired. The reconstruction of chronic ATR with FHLT transfer provided a good functional outcome and excellent patient satisfaction.

\section{ACKNOWLEDGEMENTS}

We would like to acknowledge Tiina Kaistila, sports physiologist, for assisting with strength measurements and gait analysis. 


\section{REFERENCIES}

[1] Simmonds FA. The diagnosis of the ruptured Achilles tendon. Practitioner 1957 Jul;179(1069):56-58.

[2] Reddy SS, Pedowitz DI, Parekh SG, Omar IM, Wapner KL. Surgical treatment for chronic disease and disorders of the achilles tendon. J Am Acad Orthop Surg 2009 Jan;17(1):3-14.

[3] Maffulli N, Ajis A. Management of chronic ruptures of the Achilles tendon. J Bone Joint Surg Am 2008 Jun;90(6):1348-1360.

[4] Wapner KL, Pavlock GS, Hecht PJ, Naselli F, Walther R. Repair of chronic Achilles tendon rupture with flexor hallucis longus tendon transfer. Foot Ankle 1993 Oct;14(8):443-449.

[5] Hahn F, Meyer P, Maiwald C, Zanetti M, Vienne P. Treatment of chronic Achilles tendinopathy and ruptures with flexor hallucis tendon transfer: clinical outcome and MRI findings. FootAnklelnt 2008

[6] Elias I, Besser M, Nazarian LN, Raikin SM. Reconstruction for missed or neglected Achilles tendon rupture with $\mathrm{V}$-Y lengthening and flexor hallucis longus tendon transfer through one incision. Foot Ankle Int 2007 Dec;28(12):1238-1248.

[7] Park YS, Sung KS. Surgical reconstruction of chronic achilles tendon ruptures using various methods. Orthopedics 2012 Feb;35(2):213-218.

[8] Wegrzyn J, Luciani JF, Philippot R, Brunet-Guedj E, Moyen B. Besse JL. Chronic Achilles tendon rupture reconstruction using a modified flexor hallucis longus transfer. International Orthopaedics 2010 Dec;34(8):1187-1192.

[9] Yeoman TF, Brown MJ, Pillai A. Early post-operative results of neglected tendo Achilles rupture reconstruction using short flexor hallucis longus tendon transfer: a prospective review. Foot 2012 Sep;22(3):219-223.

[10] Monroe MT, Dixon DJ, Beals TC, Pomeroy G, Crowley DL, Manoli A. Plantar flexion torque following reconstruction of Achilles tendinosis or rupture with flexor hallucis longus augmentation. Foot Ankle Int 2000 Apr;21(4):324-329.

[11] Mahajan RH, Dalal RB. Flexor hallucis longus tendon transfer for reconstruction of chronically ruptured Achilles tendons. Journal of Orthopaedic Surgery 2009 Aug;17(2):194198 
[12] Lee KB, Park YH, Yoon TR, Chung JY. Reconstruction of neglected Achilles tendon rupture using the flexor hallucis tendon. Knee Surg Traumatol Arthrosc. 2009 Mar;17(3):316320.

[13] Wilcox DK, Bohay DR, Anderson JG. Treatment of chronic achilles tendon disorders with flexor hallucis longus tendon transfer/augmentation. Foot Ankle Int 2000 Dec;21(12):10041010.

[14] Lin JL, Tendon Transfers for Achilles Reconstruction. Foot Ankle Clin Am 2009 Dec;14(4):729-44.

[15] Nilsson-Helander K, Thomee R, Gravare-SilbernagelK,et al. The Achilles tendon Total Rupture Score (ATRS): development and validation. Am J Sports Med. 2007 Mar;35(3):421426.

[16] Will RE, Galey SM. Outcome of single incision flexor hallucis longus transfer for chronic Achilles tendinopathy. Foot Ankle Int 2009 Apr;30(4):315-317.

[17] Porter DA, Mannarino FP, Snead D, Gabel SJ, Ostrowski M. Primary repair without augmentation for early neglected Achilles tendon ruptures in the recreational athlete. Foot Ankle Int. 1997 Sep;18(9):557-564.

[18] Yasuda T, Kinoshita M, Okuda R. Reconstruction of chronic Achilles tendon rupture with the use of interposed tissue between the stumps. Am J Sports Med. 2007 Apr;35(4):582-588

[19] Richardson DR, Willers J, Cohen BE, Davis WH, Jones CP, Anderson RB. Evaluation of the hallux morbidity of single-incision flexor hallucis longus tendon transfer. Foot Ankle Int. 2009 Jul;30(7):627-630.

[20] Coull R, Flavin R, Spephens MM. Flexor hallucis longus tendon transfer: evaluation of postoperative morbidity. Foot ankle Int 2003 Dec;24(12)93 


\section{TABLE 1: Characteristics of the study subjects}

\begin{tabular}{|c|c|c|c|c|c|c|c|c|}
\hline & & & $\begin{array}{l}\text { Rupture- } \\
\text { surgery }\end{array}$ & $\begin{array}{l}\text { Follow- } \\
\text { up }\end{array}$ & & & Cortison & \\
\hline Patient & Sex & Age & (mo) & (mo) & Defined diagnosis & Previous surgery & infiltrations & Smoking \\
\hline 1 & $\mathrm{M}$ & 37 & 3 & 39 & deep wound infection & $\begin{array}{l}\text { tendorraphy, revision, } \\
\text { Lindholm's plastia }\end{array}$ & no & no \\
\hline 2 & $\mathrm{~F}$ & 69 & 3 & 37 & neglected rupture & none & yes & yes \\
\hline 3 & $M$ & 50 & 52 & 24 & $\begin{array}{l}\text { rerupture, failed } \\
\text { conservative treatment }\end{array}$ & tendorraphy & no & no \\
\hline 4 & M & 37 & 18 & 24 & $\begin{array}{c}\text { lack of strength, no } \\
\text { rerupture }\end{array}$ & tendorraphy & no & no \\
\hline 5 & M & 50 & 5 & 26 & $\begin{array}{l}\text { rerupture, failed } \\
\text { conservative treatment }\end{array}$ & tendorraphy & no & yes \\
\hline 6 & $\mathrm{~F}$ & 67 & 18 & 19 & $\begin{array}{c}\text { failed conservative } \\
\text { treatment }\end{array}$ & none & yes & no \\
\hline 7 & $\mathrm{~F}$ & 61 & 12 & 16 & neglected rupture & tendorraphy & yes & yes \\
\hline mean & & 53 & 16 & 27 & & & & \\
\hline
\end{tabular}


TABLE 2: ATRS scores, side-to-side differences (\% from nonoperated) in ROM, isokinetic plantar flexion strength and cross-sectional areas of FHL and calf.

Side-to-side difference

\begin{tabular}{|c|c|c|c|c|c|c|c|}
\hline Patient & ATRS score & $\begin{array}{c}\text { Plantar flexion } \\
\text { ROM (\%) }\end{array}$ & $\begin{array}{l}\text { Dorsiflexion } \\
\text { ROM (\%) }\end{array}$ & $\begin{array}{l}\text { Plantar flexion } \\
\text { strength } \\
(\%, 30(1 / \mathrm{s}))\end{array}$ & $\begin{array}{l}\text { Plantar flexion } \\
\text { strength } \\
(\%, 90(1 / \mathrm{s}))\end{array}$ & $\begin{array}{c}\text { FHL cross- } \\
\text { sectiona area } \\
(\%) \\
\end{array}$ & $\begin{array}{c}\text { Calf total } \\
\text { cross- } \\
\text { sectional area }\end{array}$ \\
\hline 1 & 93 & -21.7 & -50 & -23.4 & 10.9 & 8.6 & -13.0 \\
\hline 2 & 88 & -14.8 & -13 & 2.4 & -17.7 & 103.7 & 6.6 \\
\hline 3 & 62 & -20.8 & -10 & -45.7 & -46.3 & 66.7 & -17.3 \\
\hline 4 & 45 & 0.0 & -19 & -40.8 & -46.2 & 62.5 & -13.5 \\
\hline 5 & 96 & -29.8 & -59 & 41.3 & 6.4 & 38.0 & -2.4 \\
\hline 6 & 38 & -49.0 & -56 & -29.1 & -70.0 & 36.8 & -25.8 \\
\hline 7 & 36 & 20.0 & 20 & -17.5 & -24.3 & 44.4 & -20.3 \\
\hline mean & 65 & 16.6 & -27 & -16.1 & -26.7 & 51.5 & -12.2 \\
\hline
\end{tabular}




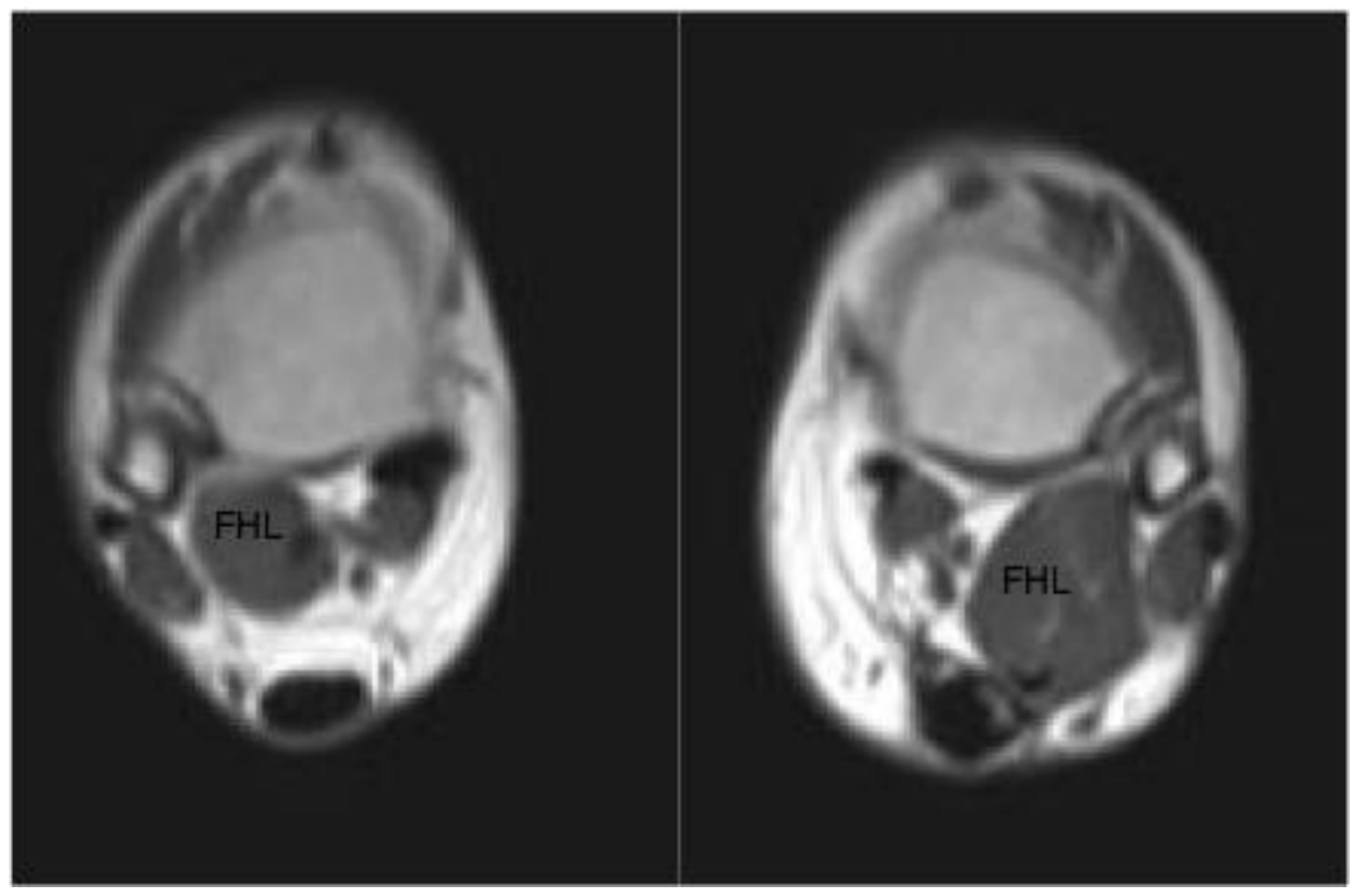

FIGURE 1: Marked hypertrophy of the Flexor Hallucis Longus (FHL) muscle three years after FHL tendon transfer due to chronic achilles tendon rupture in 69-yr-old woman. 


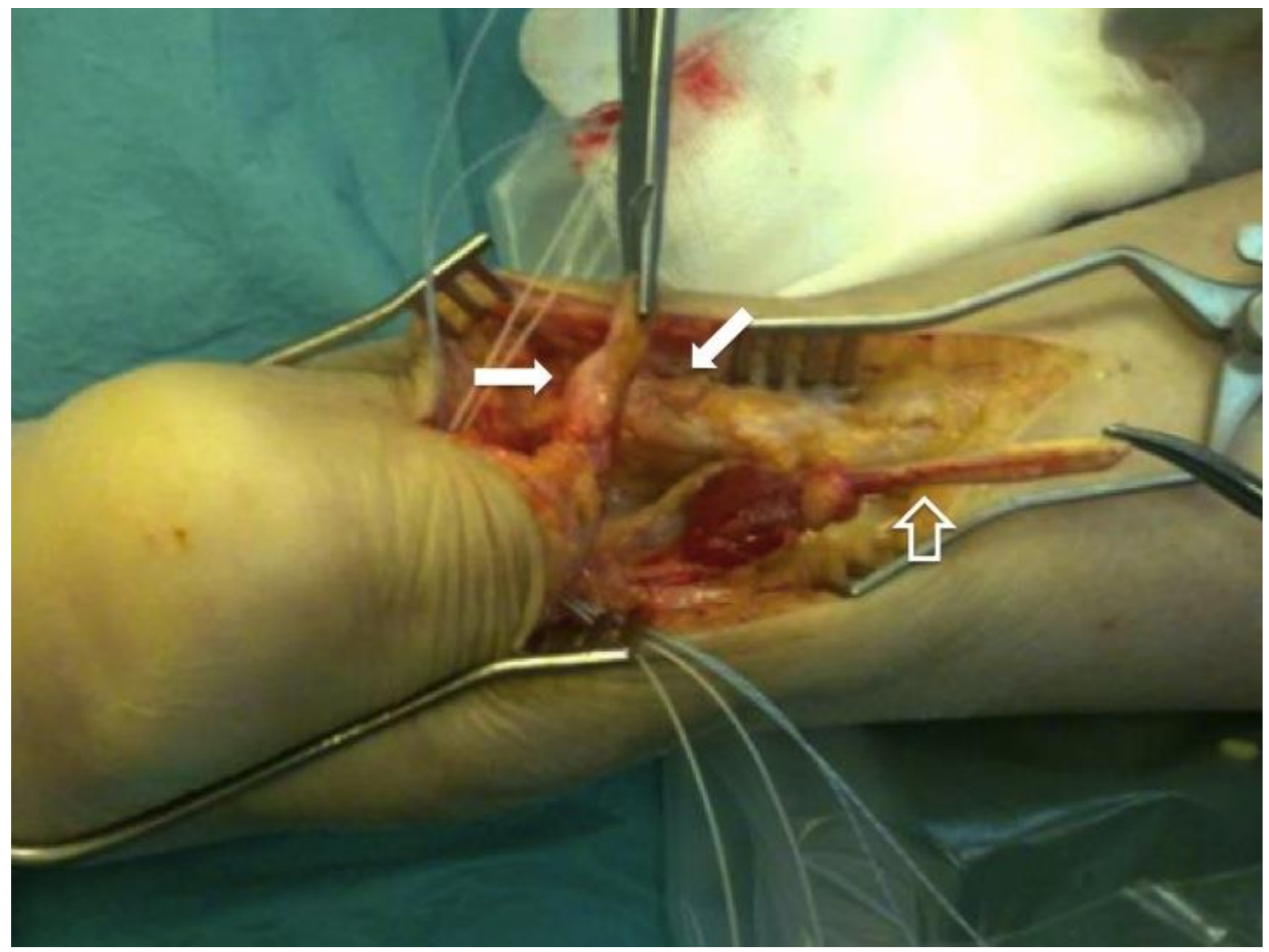

FIGURE 2 The surgical field of Flexor Hallucis Longus Transfer through single incision. Proximal and distal Achilles tendon stumps (solid arrows). FHLT (open arrow). 